Board of Governors of the Federal Reserve System

International Finance Discussion Papers

Number 595

November 1997

\title{
GLOBALIZATION AND PRODUCTIVITY \\ IN THE \\ UNITED STATES AND GERMANY
}

\author{
Catherine L. Mann
}

NOTE: International Finance Discussion Papers are preliminary materials circulated to stimulate discussion and critical comment. References in publications to International Finance Discussion Papers (other than an acknowledgment that the writer has had access to unpublished material) should be cleared with the author or authors. Recent IFDPs are available on the Web at www.bog.frb.fed.us. 


\title{
GLOBALIZATION AND PRODUCTIVITY IN THE UNITED STATES AND GERMANY
}

\author{
Catherine L. Mann*
}

\begin{abstract}
This paper investigates the impact of globalization on productivity growth and the procyclicality of productivity growth in manufacturing industries in the United States and Germany. For U.S. industries, the analysis suggests that changes in international demand affects productivity growth differently from changes in exposure to international competition. An increase in foreign demand for U.S. exports raises trend productivity growth, but to a lesser degree than does a similar demand shock from domestic buyers. On the other hand, whereas an increase in U.S. imports reduces trend productivity growth of U.S. industries, a loss of market share to imports is associated with gains to productivity growth. For Germany, neither international demand shocks nor exposure to international competition seem to be associated with productivity growth rates, perhaps because German industries experienced a smaller increase in exposure to international competition over the time period. Comparing the U.S. and German results suggests that "going global" may affect productivity growth rates more than simply "being global". As for the procyclical characteristics of productivity growth, the U.S. and German measures evidence different procyclical behavior. For many industries, both U.S. and German labor productivity growth rates exhibit some degree of procyclicality. For German industries, this procyclicality of productivity growth disappears with broader measures of productivity growth that include utilization of capital and intermediates inputs. For U.S. industries, the degree of procyclicality increases when productivity growth is measured on these broader bases. Moreover, in the United States, procyclicality appears to be accentuated by export demand growth and dampened by import demand growth.
\end{abstract}

Keywords: globalization, trade, productivity, procyclicality

* Catherine Mann is Assistant Director in the International Finance Division of the Federal Reserve Board. This paper was prepared for the conference: "Globalization, Technological Change, and the Welfare State" at the American Institute for Contemporary German Studies of the Johns Hopkins University on June 8-10, 1997. The views in this paper are solely the responsibility of the author and should not be interpreted as reflecting the views of the Board of Governors of the Federal Reserve System or of any other person associated with the Federal Reserve System. 


\section{Introduction}

This paper investigates the impact of globalization on productivity in manufacturing industries in the United States and Germany. Using disaggregated data from the manufacturing sectors in Germany and the United States, I investigate two hypotheses of how globalization and productivity might be related. The first hypothesis investigates the relationship between globalization and changes in the productivity growth rate. The second hypothesis investigates the importance of globalization for the procyclical characteristics of productivity. Globalization is proxied by real exports and imports, both real volumes and as a share of output and apparent domestic consumption, respectively. Productivity is measured three ways: (1) Labor productivity; (2) A Solow residual from a calculation including labor and utilization-adjusted capital; (3) A Solow residual from a calculation including labor, materials, and utilization-adjusted capital. The time period analyzed is 1979 to 1995 for the United States and 1981 to 1994 for Germany.

For U.S. industries, the analysis suggests that international demand growth affects trend productivity growth differently from the effect of greater international exposure. Increased export demand is associated with an increase in trend productivity growth; but this increase is less than is associated with an increase in domestic shipments. Thus, the positive correlation between productivity growth and the share of exports in output found by some other researchers is not corroborated by this study. ${ }^{1}$ On the other hand, while increased import growth is associated with lower trend productivity growth, an increase in import competition (measured by the share of imports in domestic demand) increases trend productivity growth. Thus, whereas increased imports apparently do not induce productivity enhancements, loss of market share to imports does. Comparing across the measures of productivity growth, labor markets do not bear the brunt of the reallocation of inputs necessary to achieve productivity gains; reallocations in the use of materials is particularly important for raising productivity growth rates. Capital utilization is more affected by the overall level of output, regardless of source or destination.

${ }^{1}$ See for example, the work of J. Bradford Jensen and Nathan Musick, Andrew B. Bernard and J.Bradford Jensen, and Martin Neil Baily and Jans Gersbach. 
For Germany, no element of international demand or exposure seems to be related to productivity growth rates. ${ }^{2}$ One reason for this different behavior could be the difference in initial and subsequent international demand and exposure. German industries generally started the period under examination with a much higher share of output exported and a much higher share of domestic demand satisfied by imports. A smaller additional share of German output was exported over the period, and import penetration rates also grew more slowly. By the end of the period, however, the exposure of U.S. and German industries, as defined by exports as a share of output and imports as a share of domestic consumption, are fairly similar.

Further examination of the German data suggests another reason why it may be difficult to find any relationship between productivity growth and globalization: average productivity growth over the period varies quite substantially across the alternative measures. For the U.S. calculations, the productivity measures corroborate each other as to which industries are ones with high average productivity growth rates; but, for Germany, the three measures of productivity growth do not move together. Instead, for many of the industries, the productivity growth measures other than labor productivity are negative, indicating a deterioration in the efficiency in the use of non-labor resources over time.

As for the procyclical characteristics of productivity growth, the U.S. and German measures evidence different procyclical behavior. For many industries, both U.S. and German labor productivity growth rates have some degree of procyclicality. For German industries all procyclicality of productivity growth rates disappears with the broader measures; this would appear to be associated with the negative productivity growth of these broader measures for many industries, and is consistent with the results of other researchers. ${ }^{3}$ But, for the U.S. industries, the degree of procyclicality increases when productivity growth rates are measured on a broader basis to include capital and materials utilization. Moreover, the

\footnotetext{
${ }^{2}$ These results differ from those of Fitzenberger. He uses a sample period that begins in 1975 .

${ }^{3}$ See Gebhard Flaig and Viktor Steiner.
} 
degree of procyclicality appears to be related to both export and import demand growth. Export growth accentuates procyclicality, particularly through an effect of capital utilization. Import growth appears to dampen procyclicality through the capital channel.

The structure of the paper is as follows: The next section reviews the construction of the different measures of productivity and discusses how globalization might affect productivity. Section III describes the data and how each of the measures of productivity was implemented with the data. Section IV analyzes the results for the United States and for Germany. Section V offers some final remarks.

\section{Measures of productivity growth and the role for globalization}

Measures of productivity growth

There is no standard measure of productivity growth, nor a standard by which to judge which of these might best measure technological change. Accordingly, I examine three measures. Each is the residual from the calculation of the difference between the log change in a measure of real output (a value-added measure- $\boldsymbol{y}$ or a gross-output measure- $\boldsymbol{q}$ ) and the log change in measures of real inputs (including, variously weighted, labor $-\boldsymbol{l}$, capital services $-\boldsymbol{k}$, and materials $-\boldsymbol{m}$ ).

1. Labor input measure of productivity:

\section{Labor $=y-l$}

Labor productivity is a good place to start. Since it has the fewest variables and since it does not require a decision about how to account for other inputs or the returns to scale in production, it is easiest to implement with the data and is less prone to misinterpretation--labor productivity growth is what it is. On the other hand, labor productivity growth is limited as it does not indicate how firms adjust inputs to achieve output gains, and it clearly is not a measure of technology. Many forces other than technological change can affect labor productivity-in particular a change in the capital-labor ratio.

2. Solow residual measure of productivity growth:

$$
\text { Solow }=\boldsymbol{y}-\alpha * l-(1-\alpha) * \lambda * \boldsymbol{K} \quad \alpha \text { is the labor share in nominal value added }
$$

$\boldsymbol{K}$ is the capital stock; capital services are proportional 
to $\boldsymbol{K}$ with factor of proportionality $\lambda$.

The Solow residual is the benchmark against which many other productivity measures are judged. Unfortunately, while clear as a theory, the assumption that capital services are proportional to the capital stock often yields unsatisfactory movements in the original Solow measure of productivity when implemented with data.

3. Labor and capital utilization-adjusted measure of productivity growth:

$K \& L=y-\alpha * l-(1-\alpha) * k$

This measure of productivity is derived in Burnside et al. ${ }^{4}$ They assume that real gross output $(\boldsymbol{q})$ is produced using value-added $(\boldsymbol{y})$ and materials $(\boldsymbol{m})$ in a Leontief specification. As shown above, value added output $(\boldsymbol{y})$ is then produced using labor inputs $(\boldsymbol{l})$ and capital services $(\boldsymbol{k})$ according to constant returns to scale. The Leontief assumption implies that variation in the use of materials inputs cannot be a source of variation in productivity growth.

4. Labor, materials, and capital input-adjusted measure of productivity growth:

$K L M=1 /(1-\gamma)[q-\beta * l-\gamma * m-(1-\beta-\gamma) * k] ; \beta$ is the labor share in nominal gross output

$\gamma$ is the materials share in nominal gross output

$1 /(1-\gamma)$ adjustment to value-added basis $^{5}$

This productivity measure extends the previous measuring to include the productivity gains that come from a reallocation of materials inputs, as well as of other inputs. ${ }^{6}$ Basu and Fernald find that one important reason for measures of aggregate productivity to change is that shocks cause resources to be reallocated across industries--from lower-valued uses to higher valued uses. This reasoning could apply equally well to the reallocation of resources across plants within an industry.

Role for forces of globalization

${ }^{4}$ Craig Burnside, Martin Eichenbaum, and Sergio Rebelo (1995).

${ }^{5}$ This simple adjustment is correct if we assume that the markup of price over cost does not change; see discussion of this assumption is Basu and Fernald, pp 25-26.

${ }^{6}$ This specification can also be found in Burnside, et al. 
Globalization, as proxied by trade, could affect the trend productivity growth rate and could affect the procyclicality of the productivity measures. The following decomposition of output points out two channels: the growth of real exports and real imports, and changes in the share of exports in output and in the share of imports in domestic demand. Total output $(\boldsymbol{Q})$ equals the amount produced to satisfy domestic consumption $(\boldsymbol{D})$ as well as to satisfy export demand $(\boldsymbol{X})$. On the other hand, total output is reduced by the amount of domestic consumption that is satisfied by imports $(\boldsymbol{M})$. Thus, the growth in total output can be calculated as:

\section{$d Q / Q=d D / D * D / Q+d X / X * X / Q-d M / M * M / D$}

However, for globalization per se to affect productivity, international sales or forces of international competition must elicit a different response from the firm than do domestic sales or domestic competition. Suppose a firm responds to demand shocks coming from exports or imports differently than it does to a shock to domestic demand. Changes in the growth rate of imports or exports would affect productivity growth differently than a similar change in growth of domestic demand. In addition, changes in the share of exports in output or in imports in domestic demand would affect the importance of the international shocks.

Why should firms react differently to international shocks? Firms might respond differently to international shocks because these shocks convey different information about production techniques than do domestic shocks. Imported goods can be "reverse engineered", which teaches firms foreign production technology. In addition, if among import competing firms some are more efficient and cost-effective producers, these firms will survive import competition longer than other import competing firms, thus raising the average productivity growth rate of all firms that survive. On the export side, firms that export a high fraction of their product could have a more flexible and efficient production technology which increases their ability to meet foreign design demands. Moreover, firms that do export may be the most cost effective producers world-wide of a particular product. Bernard and Jenson suggest that, for the United States, firms that export are also the most efficient producers 
and the technology leaders in an industry.

On the other hand, international competition could hurt productivity growth. Increases in import market share might contribute to a deterioration of the productivity of the domestic industries as output falls--ultimately the domestic industry would disappear. Gearing up to export to many countries, although in the long-run contributing to higher productivity growth, could initially hurt productivity growth as firms figure out how to sell into markets with different standards and tastes.

The differential response of firms to international forces can affect the procyclicality of productivity measures. To the extent that firms reallocate resources less in response to shocks that they perceive to emanate from the international dimension (either export shocks or import shocks), then procyclicality overall could be augmented or dampened, depending on whether the shock was positive or negative.

To summarize, there are three hypotheses to test on the relationship between globalization and measures of productivity growth. The first two focus on the long-run, crosssectional relationship between increased globalization--measured either as a change in growth of exports or imports or as a change in the share of exports and imports--and changes in the trend rate of growth of productivity. The third focuses on the role for globalization to accentuate or damp the procyclicality of productivity and output.

\section{Data and Empirical implementation}

\section{U.S. and German Data}

Table 1 lists the industries examined for the United States and for Germany. For the United States, all data are either annual or annualized monthly data for the time period 1978 to 1995. All are manufacturing industries and most produce either inputs or finished products destined for the manufacturing sector. Shipments, value-added output, and producer prices; factor inputs and factor 
prices; and trade values and trade prices are matched by industry code ${ }^{7}$; the same index of materials and components for manufacturing was used for all industries. ${ }^{8}$

For Germany, all data are annual for the time period 1981 to 1994 . The set of German industries includes basic inputs, capital goods, and finished/consumer goods. Thus the sample of German industries includes more output destined for the household sector, as compared to the U.S. data sample. Gross-output, value-added output and producer prices; factor inputs and factor prices; and trade values and trade prices are matched by industry code; the materials input price index and energy price index are the same for all industries. ${ }^{9}$

Empirical implementation

The empirical implementation of the calculations outlined in Section II is not completely straightforward and not entirely consistent across the two countries. For example, the measure of (the log change) in labor input is the (log change in) number of production workers for the United States, but is the (log change in) the wage bill less (log change in) average hourly wage for Germany. Which data to use to proxy for capital services is particularly difficult. Following Burnside et.al, I use (log change in) kilowatt hours for the U.S. industries. For Germany, capital services is proxied by the (log change in) energy bill less (log change in) energy price. Finally, an important data issue is that industry-specific producer prices were used to deflate both U.S. shipments and German gross-output (which is appropriate) and value-added output (which is not correct). ${ }^{10}$ Tables 2 and 3

${ }^{7}$ The trade data are end-use codes matched to the SIC codes of the industry and factor data. The output and input data are from the Annual Survey of Manufactures. The producer price and wage data are from the Bureau of Labor Statistics. The trade data are from the Department of Commerce.

${ }^{8}$ It would be superior to calculate industry-specific materials deflators using an input-output table, but data on disaggregated materials inputs and their prices are not available for the sample period investigated here. The NBER Productivity database has a fuller range of industries, but a less-up-todate time period. The more recent data were desirable given the focus on the effect of globalization.

${ }^{9}$ Data on energy usage shortened the time period. All data are from Statistisches Bundesamt.

${ }^{10}$ The lack of a value-added price index may be important for interpreting some of the results of the empirical implementation of the algebraic specifications of the previous section. The lack of a valueadded price index implies that the capital- and material-adjusted indexes differ more in principle than in 
describe more precisely the series and transformation used in the implementation.

practice. That is, in principle, we have a true measure of real value added, and that differs from real gross output. However, in practice, we have nominal value added and nominal gross output and only one price deflator. What this implies is that $\boldsymbol{K} \boldsymbol{\&} \boldsymbol{L}$ and $\boldsymbol{K} \boldsymbol{L M}$, as implemented, differ in a specific way:

$$
K L M=K \& L-\gamma /(1-\gamma)\left(d P_{\text {mat }} / P_{\text {matl }}-d P_{\text {output }} / P_{\text {output }}\right)
$$

If materials prices are rising faster than output prices, the capital and materials-adjusted productivity residual $(\boldsymbol{K} \boldsymbol{L M})$ will be smaller than the capital-utilization adjusted residual $(\boldsymbol{K} \boldsymbol{\&} \boldsymbol{L})$. If the relationship between the two prices is changing over time, and changing across industries, it could influence our interpretation of how industries achieve productivity gains through input reallocation. 


\section{Results and Discussion}

\section{Productivity Measures}

The first step is simply to look at the different productivity measures in several ways: time series, procyclicality, and cross-correlation. Charts 1 and 2 show, for selected U.S. and German industries respectively, the time series representations of the three productivity measures. As is common, the time series are quite volatile and it is difficult to discerne procyclicality or whether there is any trend in the productivity growth rates.

Tables 4 and 5 show coefficients of procyclicality for each industry for each of the three measures of productivity growth for the United States and for Germany. The coefficient of procyclicality is derived from a simple regression of the productivity measure against a constant and (log change in) contemporaneous real shipments for the time period 1978 to 1995 for the United States, and against a constant and (log change in) real gross output for the time period 1981 to 1994 for Germany.

For many industries, both U.S. and German labor productivity growth rates have some degree of procyclicality. For German industries any degree of procyclicality of productivity growth rates apparently disappears with the broader measures of producitivity growth. This may be associated with the negative productivity growth of these broader measures for many industries and, in any case, is consistent with the results of other researchers. ${ }^{11}$ For the U.S. industries, the degree of procyclicality increases when productivity growth rates are measured on a broader basis to include capital and materials utilization.

\footnotetext{
${ }^{11}$ See Gebhard Flaig and Viktor Steiner.
} 


\section{Productivity Means}

Measuring the trend rate of productivity growth is difficult, as is judging whether that trend rate has changed. Charts 3 and 4 show the sample means for the three productivity measures for each industry in the U.S. and Germany. The first observation from the U.S. productivity measures is that the means of the three measures are broadly consistent across industries-those industries with low means and those with high means are generally the same regardless of the productivity measure. The second observation is that across the different measures of productivity, labor productivity is often the highest of the three measures, except for industries with the highest rate of growth of productivity when capital and materials are accounted for, such as $365,366,367$. The labor productivity measure would generally have a mean higher than the other two measures since all the residual between input and output is being ascribed to labor. When the other productivity growth measures, which account for the use and reallocation of multiple inputs, have a higher mean, it suggests that the shares of capital and/or materials inputs into the production process for these industries are falling.

In contrast to the U.S., the means of the different German measures are not broadly consistent for an industry sector--there is no clear pattern of high-productivity or low-productivity sectors, regardless of the measure. What is more notable is the great degree to which, across industries, the three productivity growth measures differ from each other. Whereas the mean of the labor productivity measures are generally large and positive, some of the labor- and capital-adjusted productivity growth measures and many of the labor-, capital-, and materials-adjusted measures have negative means--suggestive of a declining rate of growth of productivity in the use of these inputs. ${ }^{12}$

A last way to describe the relationship between the three measures of productivity growth is to take the correlation of their sample means, as shown in Table 6. The means of the three measures of productivity are correlated with each other, but to differing degrees. The labor and labor-

\footnotetext{
${ }^{12}$ This observation of high labor productivity growth but negative growth rate of productivity when measured to include inputs other than labor is consistent with the rise in unemployment and the rise in the capital/labor ratio in Germany that others have observed in aggregate data. See for example, World Economic Outlook, IMF, May 1996, Chart 21.
} 
and capital-utilization adjusted residuals are highly correlated for both the United States and Germany. Once materials usage is included, the correlations of the mean of the productivity measures drops substantially for Germany. For the United States, all three measures are highly correlated.

\section{Patterns of globalization}

Because patterns of globalization are central to the analysis, Table 7 for the United States and Table 8 for Germany show how the two measures of globalization have changed for the two countries and for the industries. Each Table shows for each industry the share of exports in output (initialXsh) and imports in domestic demand (initialMsh) for the first year of the sample as well as the change in percentage points in those shares to the end of the sample period.

German industries generally had higher initial shares of output exported and of domestic demand satisfied by imports, as compared to U.S. industries. Almost as a consequence of this higher exposure initially, a smaller additional share of German output was exported over the period and import penetration rose less than it did for the U.S. industries. From lower initial exposures, U.S. industries experienced a much higher increase exports as a share of output and imports as a share of domestic demand. By the end of the sample period, the exposure of U.S. and German industries was similar, with German exposure somewhat higher.

\section{Globalization and productivity growth rates}

The first hypothesis asks, for an industry, whether globalization is related to productivity growth rates through either of two channels: Does industry productivity respond differently to international demand shocks than to domestic demand shocks? Are the industries with the greatest increase in productivity growth rate those with the greatest increase in international exposure (e.g. increase in exports or imports as a share of their output)?

Tables 9 and 10 show for the United States and Germany the output from regressions that are based on the discussion in Section II. The empirical approach splits the sample period, calculates the means of the variables in the two sub-sample periods, and differences the means. 
Splitting the sample and differencing yields proxies for how trends in productivity growth, domestic demand growth, export and import growth, and export and imports shares changed between the first and the second half of the sample; this also helps to eliminate industry-specific factors. A separate regression for each productivity measure is shown. Thus the regressions take the form (with variable names in italics):

[difference $($ mean $($ productivity growth rate $))]=($ labor, K\&L, KLMva)

$a^{*} \quad$ [mean (share of exports in output) in the first half of the sample] (Xsht0)

$+\boldsymbol{b}^{*} \quad$ [mean (share of imports in domestic demand) in the first half of the sample] (Msht0)

$+c^{*} \quad$ [difference(mean(growth rate of domestic shipments))] (dlDomship)

$+\boldsymbol{d}^{*} \quad[$ difference(mean(share of exports in output))] (difmnXsh)

$+\boldsymbol{e}^{*} \quad$ [difference(mean(share of imports in domestic demand))] (difmnMsh)

$+f^{*} \quad[$ difference(mean(growth rate of exports) $\left.)\right]($ dlXgrow)

$+\boldsymbol{g}^{*} \quad[$ difference(mean(growth rate of imports))](dlMgrow)

Controlling for the initial exposure to export and import competition ( $\boldsymbol{a}$ and $\boldsymbol{b})$, does productivity growth on average respond differently to mean growth of external demand than to mean growth domestic demand (e.g., are the coefficients on $\boldsymbol{f}$ and $\boldsymbol{g}$ significantly different from zero and different from $\boldsymbol{c}$ ); and how does productivity growth change as the share of exports in output changes $(\boldsymbol{d})$ and as import market share changes $(\boldsymbol{e})$ ?

Table 9 shows results for the United States. First a high percentage of the variation in the data is explained by the variables. Second, an increase in mean growth of domestic shipments is associated with an increase in mean productivity growth rate. An increase in export demand also is associated with an increase in the productivity growth rate (0.40), but to a lesser extent than the increase in domestic demand (0.57); thus increased dependence on exports as a share of output apparently reduces mean productivity--as the negative sign on the export share variable also suggests. An increase in mean import growth negatively affects mean productivity growth $(-0.10)$, although the 
deterioration in productivity growth is substantially less than it would be given a decline in domestic demand (-0.57); thus increased import competition apparently increases productivity--as the positive sign on the import market share variable also suggests. Altogether, these results suggest that losses in market share to imports stimulates producers to find more efficient ways of combining resources thus raising mean productivity growth. Export demand does support productivity, but apparently exporting is hard work. A high dependence on exports as a share of output is associated with lower mean productivity growth perhaps because it is difficult to efficiently use resources to meet varied foreign standards and tastes.

For Germany (Table 10), very little of the variation in the data is explained by either the domestic or globalization variables. It may be that German industry does not distinguish between domestic and international demand shocks because there has been relatively little increase in globalization over the sample period. The fact that domestic demand variables are also not important in explaining variations in productivity growth suggests that factors such as domestic regulation may be the driving force behind changes in trend productivity growth. This would be consistent with the very different behavior of the three measures of productivity growth. 
Trade and the procyclicality of productivity and output

The last hypothesis outlined in Section II was that the procyclicality of productivity and output might be affected by the interaction of industries' different responses to globalization with the importance of international exposure. Tables 4 and 5 showed the cofficient of procyclicality for each of the productivity growth measures for the U.S. and German industries. Tables 11 and 12 show the results of a simple regression of these procyclicality coefficients against the globalization variables: [cross-section of industry coefficients of procyclicality] $=$ (labor, K\&L, KLMva)

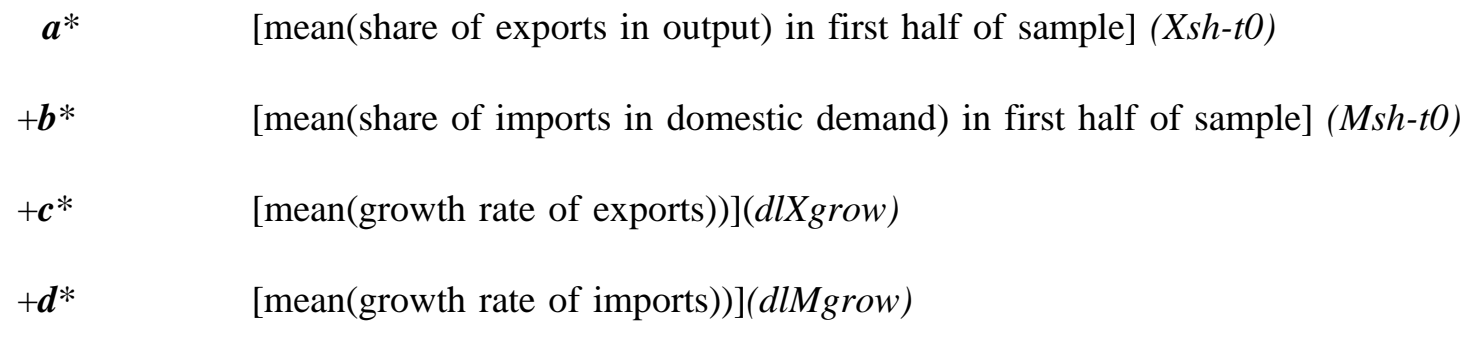

Not surprisingly, there is little evidence that labor procyclicality in Germany is related to international demand or exposure (Table 11). However, there is some evidence that procyclicality evidenced in U.S. data (Table 12) might be related to international factors--principally through the channel of capital usage. Strong export demand growth increases the procyclicality of the $\boldsymbol{K} \boldsymbol{\&} \boldsymbol{L}$ measure, whereas strong import growth would appear to dampen the coefficient of procyclicality of this measure. One explanation for this behavior is that U.S. firms base capital decisions on expected domestic demand. Higher export demand must be met with the same capital--thus raising procyclicality. Higher import demand smooths out what would be peaks in domestic demand--thus dampening procyclicality. 


\section{Final Remarks}

As an overall summary, these results suggest that for the United States but not for Germany the forces of international demand growth and competition have important and independent effects on productivity growth rates. U.S. firms respond differently to globalization than to domestic forces. One difference between the U.S. and German firms is on the extent to which international exposure increased for the U.S. firms--both exports as a share of output and imports as a share of domestic demand. Increased global competition may spur increases in productivity growth more than just simply facing the same degree of international competition.

Besides being interesting in their own right, these results feed into several important debates ongoing in the profession and in the policy community: first, the debate on the effect of globalization on labor markets and second, the debate on the origin of procyclicality.

Many studies of the impact of trade on labor markets assume that globalization and productivity growth are independent forces. ${ }^{13}$ Most of these econometric or factor analyses of employment or relative wage dispersion measure the effect of globalization with import prices or import flows, but do not account independently for productivity growth. Instead, the substantial residual unexplained effect in the regression is termed "technological change". If trade and productivity growth are interdependent forces affecting the labor market, then including only one in a simple regression will bias that coefficient: up to the extent that the two forces covary positively or down to the extent that they covary negatively. The results in this paper for the United States indicate that international demand as well as international competition affect trend productivity growth rates. Thus, the next step in research on the effects of international forces on U.S. labor markets should include export as well as import variables and should explicitly take account of productivity growth.

${ }^{13}$ For Germany, Fitzenberger op. cit. For the United States see for example: Eli Berman, John Bound, and Zvi Griliches; George Borjas and Valerie Ramey; George Borjas, Richard Freeman, and Lawrence Katz; Robert Feenstra and Gordon Hanson; Paul Krugman and Robert Lawrence; Robert Lawrence and Matthew Slaughter; Edward Leamer; Jeffrey Sachs and Howard Shatz; Adrian Wood. 
The results in this paper also are important for the research that addresses the role of technology vs. other factors in affecting, on the one hand, the procyclicality of productivity and output and, on the other hand, long-term growth. Researchers have examined various hypotheses for the source of procyclicality in U.S. data including profit margins, labor effort, capital utilization, variation in the shares of inputs, and resource reallocation across industries. ${ }^{14}$ This paper suggests that global forces of competition and technology transfer may be different from domestic forces in generating procyclical productivity, at least in the United States.

${ }^{14}$ See for example Susanto Basu; Basu and John Fernald; Mark Bils; Craig Burnside, Martin Eichengreen, and Sergio Rebelo; Ricardo J. Caballero and Richard K. Lyons; Matthew Shaprio; Robert M. Solow. 


\section{$\underline{\text { References }}$}

Baily, Martin Neil and Jans Gersbach (1995), "Efficiency in Manufacturing and the Need for Global Competition," BPEA--Microeconomics.

Basu, Susanto (1996), "Procyclical Productivity: Increasing Returns or Cyclical Utilization," Quarterly Journal of Economics, August, p.719-751.

Basu, Susanto and John Fernald (1997), "Aggregate Productivity and Aggregate Technology," manuscript, Federal Reserve Board, February.

Berman, Eli, John Bound, and Zvi Griliches (1994), "Changes in the Demand for Skilled Labor within U.S. Manufacturing Industries: Evidence from the Annual Survey of Manufactures," Quarterly Journal of Economics, February.

Bernard, Andrew B. and J.Bradford Jensen (1995), "Exceptional Export Performance: Cause, Effect, or Both?", manuscript, December.

Bils, Mark (1992), "Measuring Returns to Scale from Shift Practices in Manufacturing," manuscript, University of Rochester.

Borjas, George and Valerie Ramey (1994), "Time-Series Evidence on the Sources of Trends in Wage Inequality," American Economic Review, May.

Borjas, George, Richard Freeman, and Lawrence Katz (1991), "On the Labor Market Effects of Immigration and Trade," NBER WP no. 3761, June.

Burnside, Craig, Martin Eichenbaum, and Sergio Rebelo (1995), "Capital Utilization and Returns to Scale," in B. Bernanke and J. Rothenberg, eds., NBER Macroeconomics Annual.

(1996), "Sectoral Solow Residuals," European Economic Review, p 861-869.

Caballero, Ricardo J. and Richard K. Lyons (1992), "External Effects in U.S. Procyclical

Productivity," Journal of Monetary Economics, vol 29, pp 209-226.

Feenstra, Robert and Gordon Hanson (1995), "Foreign Investment, Outsourcing, and Relative Wages," NBER WP no. 5121, May.

Fitzenberger, Bernd (1996), "Wages, Prices, and International Trade: Trends Across Industries for an 'Export Champion'," manuscript University of Konstanz, October.

Flaig, Gebhard and Viktor Steiner (1993), "Searching for the 'Productivity Slowdown': Some Surprising Findings from West German Manufacturing," Review of Economics and Statistics.

Jensen, J. Bradford and Nathan Musick (1996), "Trade, Technology, and Plant Performance," ESA/OPD 96-4, U.S. Dept of Commerce, Economics and Statistics Administration, February.

Krugman, Paul and Robert Lawrence (1994), "Trade, Wages, and Jobs," Scientific American, April.

Lawrence, Robert and Matthew Slaughter (1993), "Trade and U.S. Wages: Great Sucking Sound or 
Small Hiccup?," BPEA--Microeconomics-BPEA.

Leamer, Edward (1996), "In Search of Stolper-Samuelson Effects on Wages" in Susan M. Collins, ed. Imports, Exports, and the American Worker, The Brookings Institution.

Sachs, Jeffrey Sachs and Howard Shatz (1994), "Trade and Jobs in U.S. Manufacturing," BPEA..

Shapiro, Mathew (1996), "Macroeconomic Implications of Variations in the Workweek of Capital," BPEA vol2, p.79-119.

Solow, Robert M. (1957), "Technological Change and the Aggregate Production Function," Review of Economics and Statistics, vol 39, p 312-320.

Wood, Adrian (1995), "How Trade Hurt Unskilled Workers," Journal of Economic Perspectives, Summer. 
Table 1: Included Industries

\begin{tabular}{|c|c|c|c|}
\hline \multicolumn{2}{|l|}{ United States } & \multicolumn{2}{|l|}{ Germany } \\
\hline Industry & Code & Industry & Code \\
\hline Basic steel products & 331 & Stone, clay, glass products & 25 \\
\hline Foundry products & 332 & Non-ferrous metal product & 28 \\
\hline Non-ferrous metal products & 333 & Chemicals & 40 \\
\hline Fasteners, stampings & 34567 & Logs and planks & 53 \\
\hline Ordnance & 348 & Pulp and plywood & 55 \\
\hline Engines, turbines & 351 & Rubber products & 59 \\
\hline Farm machinery & 352 & Various steel products & 302 \\
\hline Construction equipment & 353 & Railroad, metal girders & 31 \\
\hline Metalworking machinery & 354 & Farm machinery & 32 \\
\hline Special industrial machinery & 355 & Autos & 33 \\
\hline General industrial machinery & 356 & Electric home appliances & 36 \\
\hline Office \&computing machinery & 357 & Optics and clocks & 37 \\
\hline Service industry machinery & 358 & Iron and steel sheets & 38 \\
\hline Electrical industrial apparatus & 362 & Office machinery \&computers & 50 \\
\hline Household appliances & 363 & Musical equipment & 39 \\
\hline Lighting and wiring products & 364 & Fine ceramics & 51 \\
\hline $\mathrm{TV}$ and radio sets & 365 & Glassware & 52 \\
\hline Communication equipment & 366 & Finished wood products & 54 \\
\hline Electronic components & 367 & Finished paper products & 56 \\
\hline Misc. electrical machinery & 369 & Books & 57 \\
\hline Autos and parts & 371 & Finished plastic products & 58 \\
\hline Ships and boats & 373 & Shoes & 61 \\
\hline Scientific and medical eqpt. & 381234 & Textiles & 63 \\
\hline Photo supplies and eqpt. & 386 & Apparel & 64 \\
\hline
\end{tabular}


Table 2: Implementation for U.S. Data

For each industry code; industry code subscripts not shown

\begin{tabular}{|c|c|}
\hline & labor $=y-l$ \\
\hline$y:$ & log-change in nominal value-added less log-change in producer price \\
\hline$l:$ & log-change in production employment \\
\hline \multicolumn{2}{|c|}{ 2. Labor and capital utilization-adjusted residual: } \\
\hline & $K \& L=y-\alpha * 1-(1-\alpha) * k$ \\
\hline$y:$ & log-change in nominal value-added less log-change in producer price; \\
\hline$\alpha:$ & ratio of wage bill for production employees to nominal value added \\
\hline$l:$ & log-change in production employment \\
\hline$k$ : & log-change in kilowatt hours \\
\hline \multicolumn{2}{|c|}{ 3. Labor, materials, and capital-utilization adjusted residual: } \\
\hline & $K L M=1 /(1-\gamma) *(q-\beta * l-\gamma * m-(1-\beta-\gamma) * k)$ \\
\hline$q:$ & log-change nominal gross-output less log-change in producer prices \\
\hline$\beta$ & ratio of wage-bill for production employees to nominal gross output \\
\hline$l:$ & log-change in production employment \\
\hline$\gamma:$ & ratio of materials costs to nominal gross output \\
\hline$m$ & $\begin{array}{l}\text { log change in nominal materials costs less log change in (common) deflator for } \\
\text { materials in manufacturing }\end{array}$ \\
\hline$k$ : & log change in kilowatt hours \\
\hline
\end{tabular}


Table 3: Implementation for the German Data

For each industry code; industry code subscripts not shown

\begin{tabular}{||l|l|l||}
\hline \hline \multicolumn{1}{||l}{ 1. Labor productivity: } \\
\hline & \multicolumn{1}{l||}{ Labor $=\boldsymbol{y}$ - $\boldsymbol{l}$} \\
\hline & $\boldsymbol{y}:$ & log-change in nominal value-added less log-change in producer prices; \\
\hline 2. Labor and capital-utilization adjusted residual:
\end{tabular}




\section{Chart 1: Productivity Measures for Selected Industries: United States}
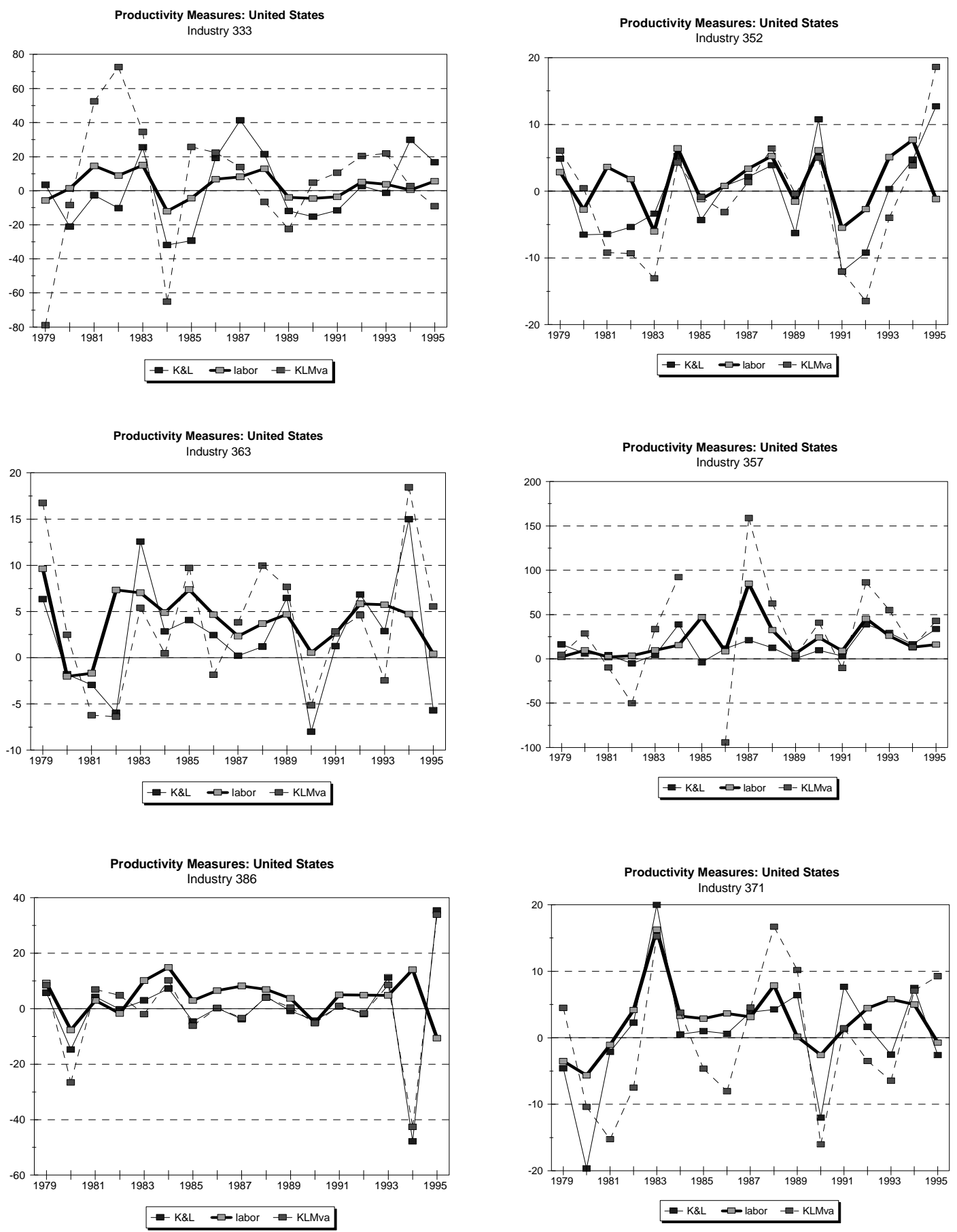


\section{Chart 2: Productivity Measures for Selected Industries: Germany}
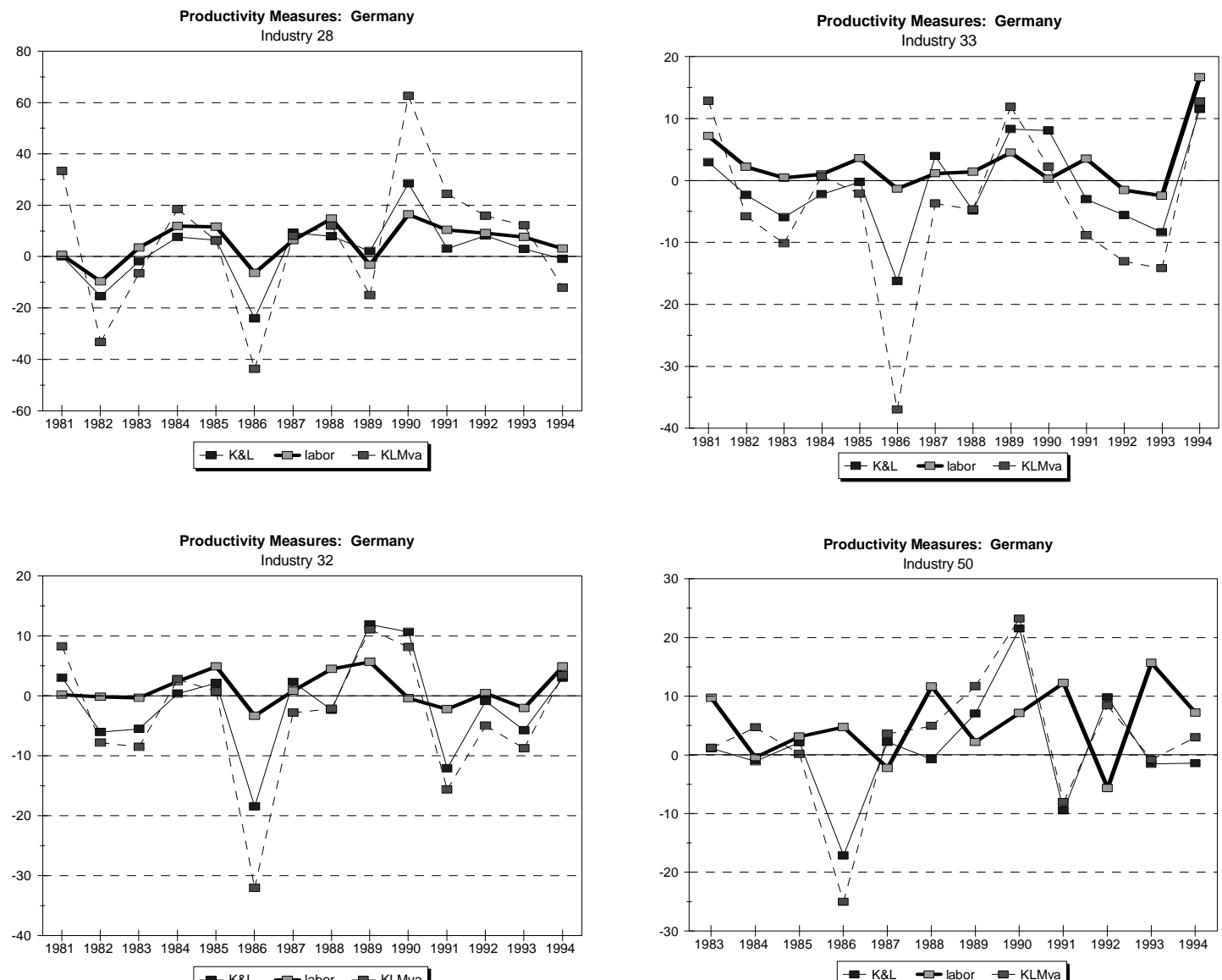

- K\&L $\rightarrow$-labor - KLMva

$$
\rightarrow \text { K\&L } \rightarrow \text { - labor } \rightarrow \text { KLMva }
$$
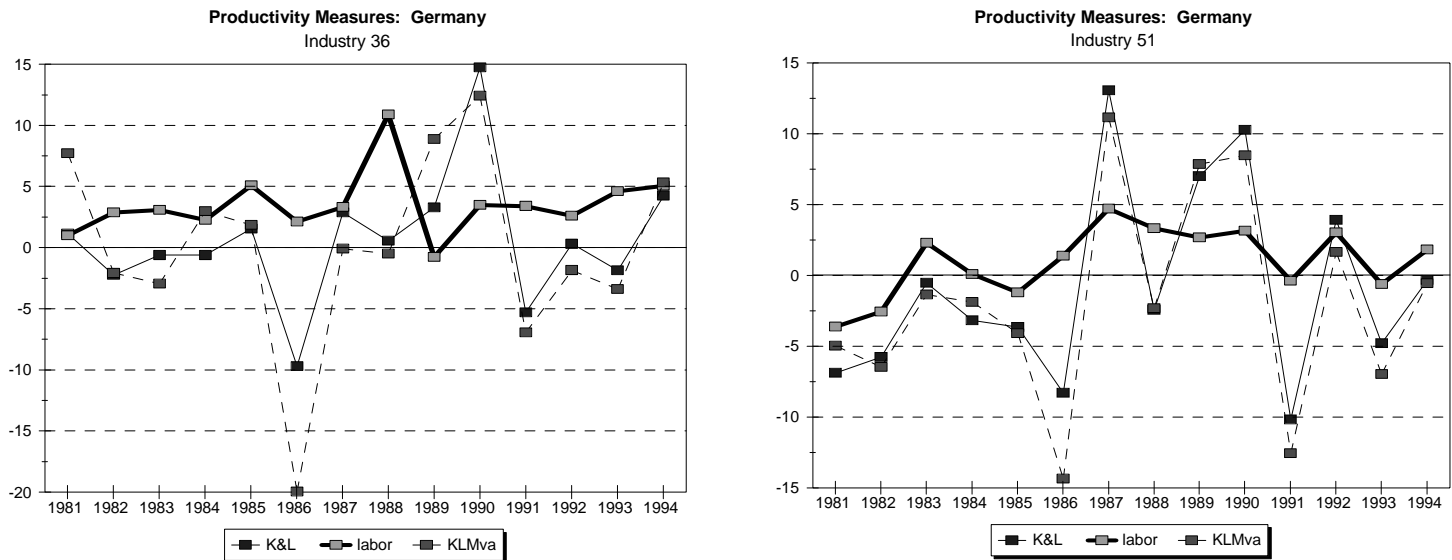


\section{Table 4: Coefficient of Procyclicality--United States}

\begin{tabular}{|c|c|c|c|c|}
\hline & & & ctivity mea & \\
\hline & & labor & $K \& L$ & KLM \\
\hline Basic steel products & 331 & 0.309 * & $0.648 *$ & 0.097 \\
\hline Foundry products & 332 & 0.13 & 0.098 & -0.054 \\
\hline Non-ferrous metals & 333 & 0.4 * & $1.75 *$ & -0.231 \\
\hline Fasteners, stampings & 34567 & 0.295 * & 0.01 & 0.062 \\
\hline Ordnance & 348 & 0.269 * & 0.106 & 0.162 \\
\hline Engines, turbines & 351 & 0.222 * & 0.378 * & 0.468 * \\
\hline Farm machinery & 352 & 0.216 * & 0.243 * & $0.375 *$ \\
\hline Construction eqpt & 353 & 0.178 * & 0.678 * & $0.499 *$ \\
\hline Metalworking mach. & 354 & 0.283 * & 0.417 * & 0.416 * \\
\hline Special ind. mach. & 355 & 0.163 & 0.165 & 0.388 \\
\hline General ind. mach. & 356 & 0.251 * & 0.354 * & 0.471 * \\
\hline Offic\&comp. mach. & 357 & 0.928 * & 0.186 & 1.74 \\
\hline Service ind. mach. & 358 & 0.113 & 0.301 & 0.449 \\
\hline Electrical ind. apparatus & 362 & 0.236 * & 0.212 & 0.657 * \\
\hline Household appliances & 363 & 0.258 * & $0.61 *$ & $0.602 *$ \\
\hline Lighting \& wiring prod. & 364 & 0.165 & 0.686 * & 0.801 * \\
\hline TV and radio sets & 365 & 0.483 * & -0.09 & -0.15 \\
\hline Communication eqpt. & 366 & 0.554 * & $0.831 *$ & 1.48 * \\
\hline Electronic components & 367 & 0.298 * & 0.717 * & 0.616 * \\
\hline Misc. electrical mach. & 369 & 0.434 * & 0.181 & $0.945 *$ \\
\hline Autos and parts & 371 & 0.299 * & $0.345 *$ & 0.394 * \\
\hline Ships and boats & 373 & 0.148 & 0.169 & 0.317 \\
\hline Scientific \& medical eqpt. & 381234 & 0.991 * & 0.047 & 1.54 * \\
\hline Photo supplies \& eqpt. & 386 & 0.867 * & -0.535 & 0.256 \\
\hline
\end{tabular}

coefficient from simple regression of productivity measure against real shipments:1978-1995 ${ }^{*}$ significant at $10 \%$ 


\section{Table 5: Coefficient of Procyclicality--Germany}

\begin{tabular}{|c|c|c|c|c|}
\hline & & & ductivity $n$ & isures \\
\hline & & labor & $K \& L$ & KLM \\
\hline Stone, clay, glass prod. & 25 & 0.443 * & 0.386 & 0.221 \\
\hline Non-ferrous fabrications & 28 & 0.351 * & 0.348 & 0.081 \\
\hline Chemicals & 40 & -4.663 & -2.13 & -2.061 \\
\hline Logs and planks & 53 & 0.486 * & 0.38 & -0.263 \\
\hline Pulp and plywood & 55 & 0.461 & 0.594 & 0.009 \\
\hline Rubber products & 59 & 0.574 * & 0.514 & 0.579 \\
\hline Various steel prod. & 302 & 0.286 * & 0.279 & -4.010 \\
\hline Metal framing \& rails & 31 & 0.363 * & 0.221 & 0.057 \\
\hline Farm machinery & 32 & 0.408 * & 0.486 & 0.614 \\
\hline Autos & 33 & 0.424 * & 0.458 & 0.643 \\
\hline Electrical home appl. & 36 & 0.148 & 0.397 & 0.404 \\
\hline Optics and clocks & 37 & 0.286 * & 0.399 & 0.452 \\
\hline Iron and steel sheets & 38 & 0.237 * & 0.504 & 0.363 \\
\hline Office mach. \& computers & 50 & 0.045 & 0.001 & 0.042 \\
\hline Musical eqpt. & 39 & 0.625 * & 0.467 & 0.512 \\
\hline Fine ceramics & 51 & 0.198 & 0.48 & 0.519 \\
\hline Glassware & 52 & 0.292 * & 0.255 & -0.038 \\
\hline Wood products & 54 & 0.303 * & 0.377 & 0.123 \\
\hline Paper products & 56 & 0.361 * & 0.682 * & 0.519 \\
\hline Books & 57 & 0.318 & 0.585 & 0.401 \\
\hline Plastic products & 58 & 0.157 & 0.425 & -0.078 \\
\hline Shoes & 62 & 0.462 & 0.533 & 0.945 \\
\hline Textiles & 63 & 0.313 * & 0.319 & 0.161 \\
\hline Apparel & 64 & 0.222 * & 0.085 & 0.337 \\
\hline
\end{tabular}

coefficient from simple regression of productivity measure against real gross output:1981-1994 ${ }^{*}$ significant at $10 \%$ 


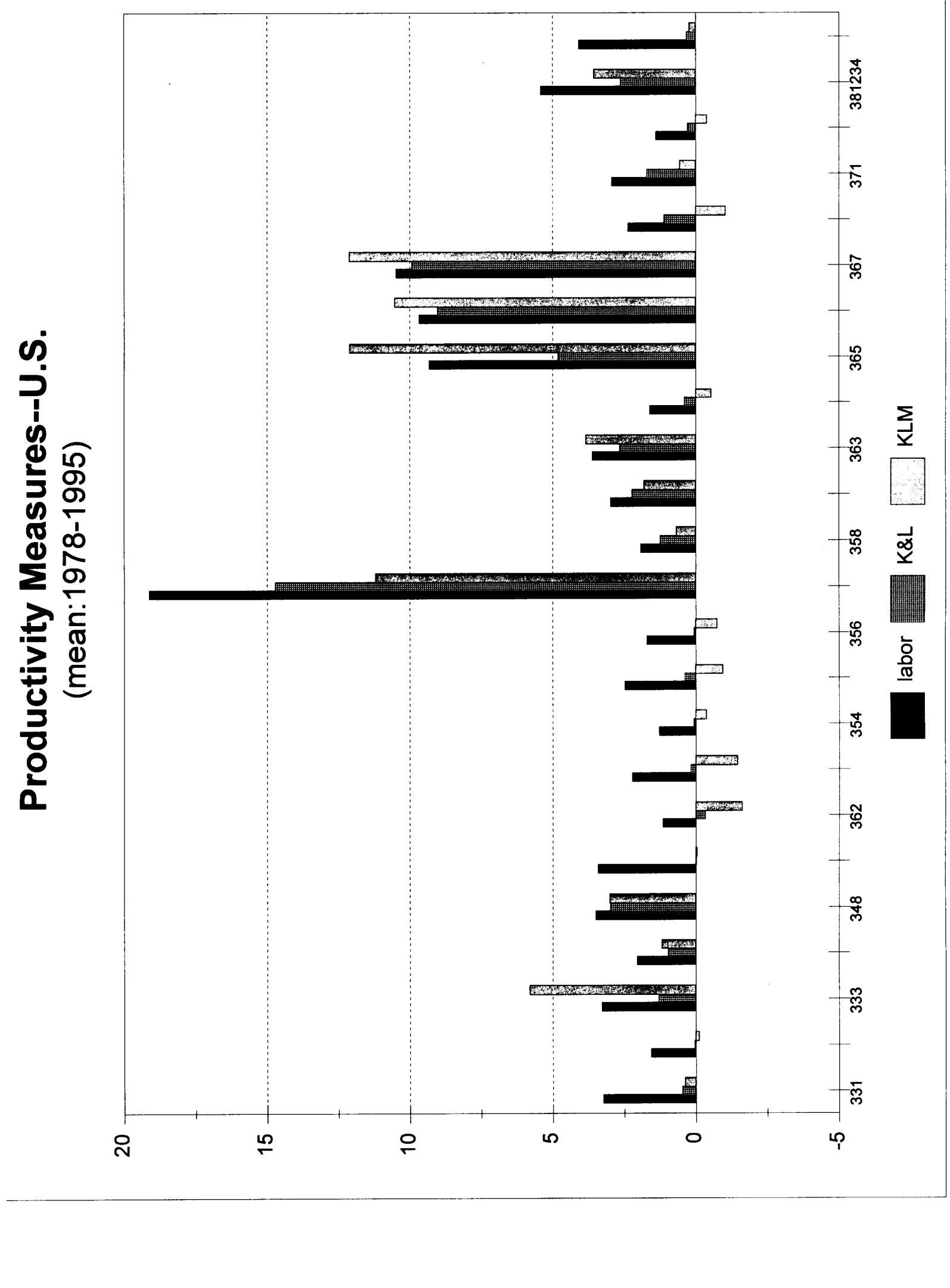




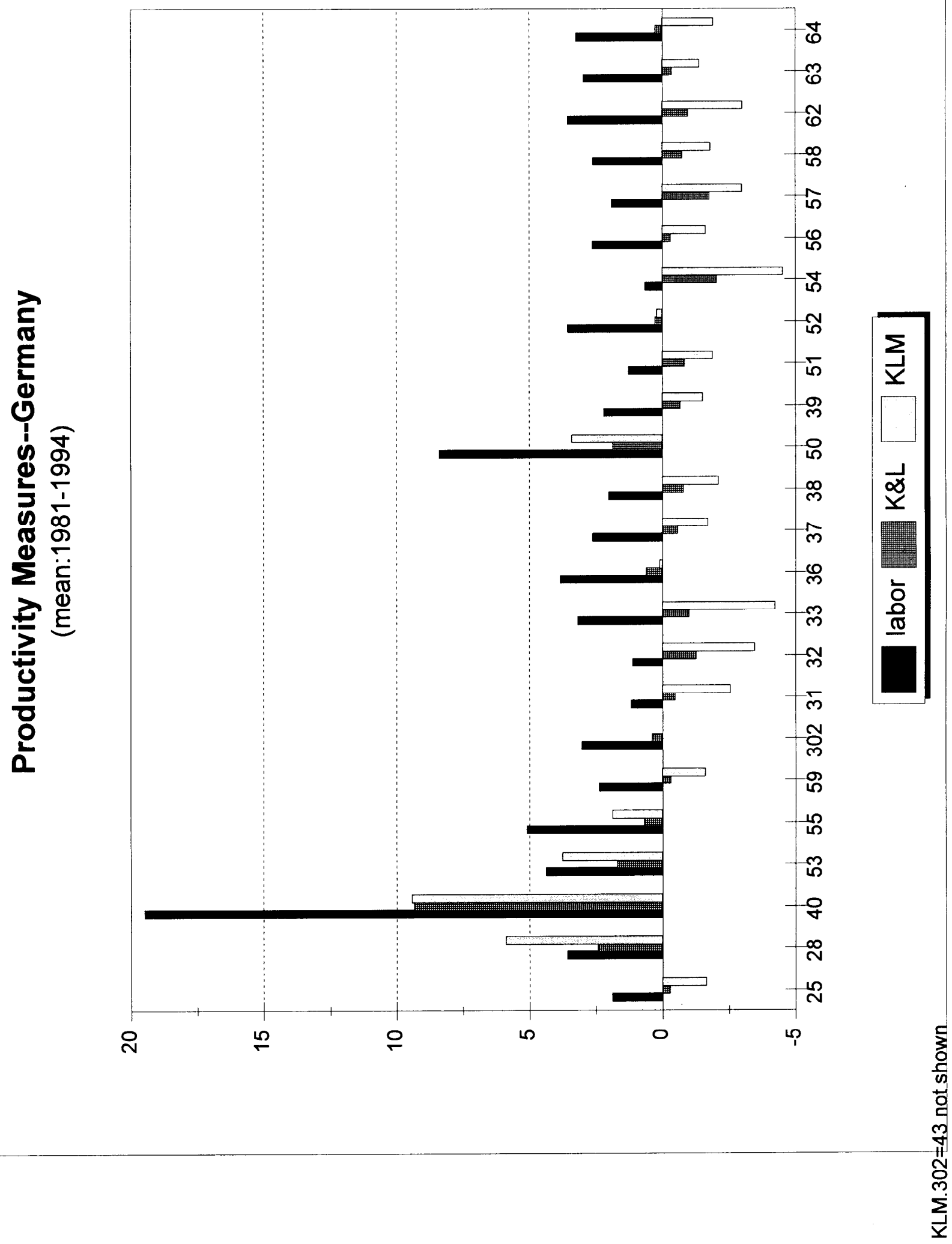




\section{Table 6: Productivity Measures: \\ Correlations of Period Means}

\begin{tabular}{|c|c|c|c|}
\hline & & \multicolumn{2}{|c|}{ Germany } \\
\hline & labor & K\&L & KLM \\
\hline labor & 1 & & \\
\hline$K \& L$ & 0.94367 & 1 & \\
\hline \multirow[t]{3}{*}{ KLM } & 0.238155 & 0.32215 & \\
\hline & & Unitec & Sta \\
\hline & labor & $K \& L$ & KLM \\
\hline labor & 1 & & \\
\hline$K \& L$ & 0.95858 & 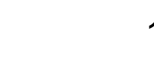 & \\
\hline KLM & 0.860876 & 0.87519 & \\
\hline
\end{tabular}




\section{Table 7: Trade Exposure--United States}

industries

Basic steel products

Foundry products

Non-ferrous metal products

Fasteners, stampings

Ordnance

Engines, turbines

Farm machinery

Construction eqpt

Metalworking mach.

Special industrial mach.

General industrial mach.

Office\&computing mach.

Service industry mach.

Eletrical industrial apparatus

Household appliances

Lighting and wiring products

TV and radio sets

Communication eqpt.

Electronic components

Misc. electrical machinery

Autos and parts

Ships and boats

Scientific and medical eqpt.

Photos supplies and eqpt.

\section{codes initialMsh initialXsh diffMsh diffXsh}

$\begin{array}{crrrr}331 & 8 & 2 & 18 & 7 \\ 332 & 37 & 9 & 29 & 34 \\ 333 & 10 & 4 & 18 & 24 \\ 34567 & 1 & 1 & 3 & 3 \\ 348 & 3 & 7 & 23 & 46 \\ 351 & 2 & 11 & 25 & 43 \\ 352 & 10 & 15 & 13 & 24 \\ 353 & 6 & 18 & 24 & 23 \\ 354 & 10 & 9 & 18 & 11 \\ 355 & 20 & 13 & 17 & 21 \\ 356 & 8 & 12 & 24 & 20 \\ 357 & 6 & 14 & 44 & 30 \\ 358 & 2 & 7 & 12 & 10 \\ 362 & 6 & 7 & 20 & 14 \\ 363 & 6 & 5 & 19 & 9 \\ 364 & 4 & 11 & 20 & 14 \\ 365 & 38 & 11 & 39 & 44 \\ 366 & 11 & 7 & 16 & 16 \\ 367 & 11 & 11 & 40 & 29 \\ 369 & 10 & 8 & 47 & 33 \\ 371 & 15 & 6 & 19 & 12 \\ 373 & 1 & 1 & 36 & 32 \\ 381234 & 5 & 14 & 9 & 17 \\ 386 & 9 & 9 & 26 & 14\end{array}$


Table 8: Trade Exposure--Germany

$\begin{array}{lrrrrr}\text { industries } & \text { codes } & \text { initialMsh } & \text { initialXsh } & \text { diffMsh } & \text { diffXsh } \\ \text { stone,clay,glass } & 25 & 11 & 11 & 3 & 5 \\ \text { non-ferrous fabrications } & 28 & 44 & 39 & 21 & 20 \\ \text { chemicals } & 40 & 23 & 38 & 12 & 9 \\ \text { logs/planks } & 53 & 34 & 17 & 6 & 8 \\ \text { pulp/plywood } & 55 & 45 & 29 & 9 & 15 \\ \text { rubber } & 59 & 21 & 24 & 11 & 7 \\ \text { various steels } & 302 & 10 & 23 & 8 & 5 \\ \text { railroad/metal framing } & 31 & 5 & 16 & 6 & 5 \\ \text { farm mach } & 32 & 17 & 45 & 11 & 7 \\ \text { autos } & 33 & 16 & 38 & 14 & 10 \\ \text { elec home appliance } & 36 & 19 & 31 & 13 & 6 \\ \text { optics/clocks } & 37 & 32 & 46 & 20 & 15 \\ \text { iron/steel sheet } & 38 & 17 & 25 & 5 & 9 \\ \text { office mach/computers } & 50 & 42 & 21 & 35 & 45 \\ \text { musical eqpt } & 39 & 52 & 56 & 15 & 10 \\ \text { fine ceramics } & 51 & 38 & 33 & 9 & 12 \\ \text { glassware } & 52 & 21 & 27 & 7 & 7 \\ \text { wood products } & 54 & 11 & 12 & 11 & 6 \\ \text { paper products } & 56 & 8 & 14 & 7 & 11 \\ \text { books } & 57 & 6 & 16 & 4 & 4 \\ \text { plastic products } & 58 & 16 & 25 & 6 & 6 \\ * * \text { shoes } & 62 & 47 & 19 & 26 & 21 \\ \text { textiles } & 63 & 41 & 39 & 33 & 29 \\ \text { apparel } & 64 & 39 & 26 & 22 & 11 \\ & & & & & \end{array}$




\section{Table 9: Globalization and Productivity Growth--United States}

regression of diff(mean(productivity) against

initial(mean(Xsh), initial (mean(Msh), diff(mean(domship grow)),

$\operatorname{diff}($ mean(Xsh), diff(mean(Msh), diff(mean(dlxgrow), diff(mean(dlMgrow)

raw:e3..e26, raw:h3..h26, diffs:m3..m26, diffs:e.3..e26, diffs:h3..h26, diffs:k3..k26, diffs:I3..126

labor

Regression Output:

\begin{tabular}{|c|c|c|c|c|c|}
\hline Constant & & 0 & & & \\
\hline Std Err of $Y$ Est & & 2.032226 & & & \\
\hline R Squared & & 0.825153 & & & \\
\hline No. of Observations & & 24 & & & \\
\hline Degrees of Freedom & & 17 & & & \\
\hline & Xsht0 & Msht0 & dIDomshipdifmnXsh & difmnMsh dlXgrow & dIMgrow \\
\hline X Coefficient(s) & -0.08255 & 0.02891 & 0.566972 & 0.4855830 .400074 & -0.10004 \\
\hline Std Err of Coef. & 0.078892 & 0.061748 & 0.089528 & $0.161901 \quad 0.089612$ & 0.044946 \\
\hline
\end{tabular}

$K \& L$

Constant

Std Err of Y Est

$R$ Squared

No. of Observations

Degrees of Freedom

Xsht0 Mshto

3.16434

0.543081

24

17
dlDomshipdifmnXsh difmnMsh dlXgrow dlMgrow

$\begin{array}{llllllll}X \text { Coefficient(s) } & 0.136883 & -0.08598 & 0.635796 & 0.328755 & -0.30469 & 0.54832 & -0.12365\end{array}$

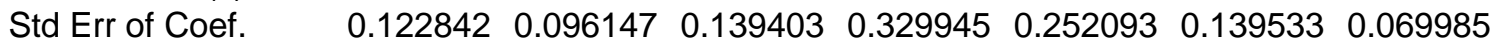

KLM Regression Output:
Constant
Std Err of $Y$ Est
0
$R$ Squared
2.668591
No. of Observations
0.762406
Degrees of Freedom
24
$X$ Coefficient(s)
Xsht0 Msht0 dIDomshipdifmnXsh difmnMsh dIXgrow dlMgrow
Std Err of Coef.
$\begin{array}{lllllll}-0.1056 & 0.069677 & 0.545038 & -0.554 & 0.600585 & 0.344174 & -0.12539\end{array}$
$\begin{array}{lllllll}0.103596 & 0.081084 & 0.117563 & 0.278253 & 0.212598 & 0.117673 & 0.059021\end{array}$ 


\section{Table 10: Globalization and Productivity Growth--Germany}

regression of diff(mean(productivity) against

initial(mean(Xsh), initial (mean(Msh), diff(mean(domship grow)),

diff(mean(Xsh), diff(mean(Msh), diff(mean(dlxgrow), diff(mean(dlMgrow)

raw:g5..g28,raw:f5..f28,diffs:J5..J28,diffs:g5..g28,diffs:f5..f28,diffs:i5..i28,diffs:h5..h28

labor

\begin{tabular}{|c|c|c|c|c|}
\hline $\begin{array}{ll} & \text { Regressio } \\
\text { Constant } & \end{array}$ & n Output: & 0 & & \\
\hline Std Err of $Y$ Est & & 7.93466 & & \\
\hline R Squared & & 0.226863 & & \\
\hline No. of Observations & & 24 & & \\
\hline Degrees of Freedom & & 17 & & \\
\hline & Xsht0 & Msht0 & dIDomshipdifmnXsh difmnMsh dlXgrow & dlMgrow \\
\hline X Coefficient(s) & -0.25443 & 0.222109 & $\begin{array}{llll}0.208607 & -0.16158 & 0.092658 & 0.139999\end{array}$ & 0.373653 \\
\hline Std Err of Coef. & 0.17329 & 0.16007 & $\begin{array}{lllll}0.699699 & 0.845924 & 0.732571 & 1.058104\end{array}$ & 0.801301 \\
\hline
\end{tabular}

$K \& L$

\begin{tabular}{|c|c|c|c|c|c|c|}
\hline Constant & utput: & 0 & & & & \\
\hline Std Err of $Y$ Est & & 3.857884 & & & & \\
\hline R Squared & & 0.056735 & & & & \\
\hline No. of Observations & & 24 & & & & \\
\hline egrees of Freedom & & 17 & & & & \\
\hline & Xsht0 & Msht0 & dIDomshipdifmnXsh & difmnMsh & dlXgrow & dlMgrow \\
\hline Coefficient(s) & 0.012161 & 0.023544 & $0.261696 \quad 0.104734$ & 0.018568 & 0.000652 & 0.298692 \\
\hline Std Err of Coef. & 0.084255 & 0.077827 & 0.3401980 .411294 & 0.356181 & 0.514457 & 0.389598 \\
\hline
\end{tabular}

KLM Regression Output:

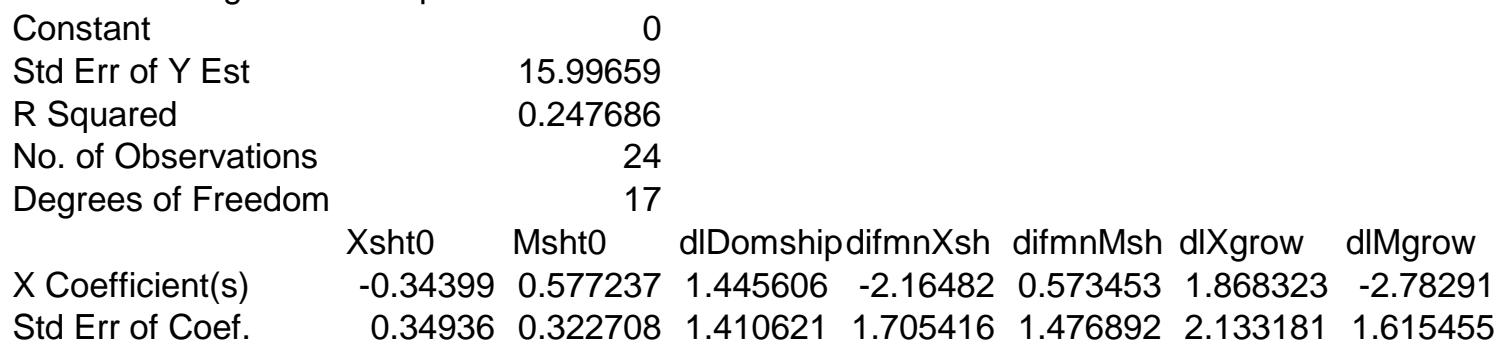




\section{Table 11: Globalization and Procyclicality--Germany}

regression of the industry-cross section of procyclicality coefficients against init(Xsh), init(msh), dlXgrowth, dlMgrowth period: $1981-1994$

\begin{tabular}{llrrr}
\multicolumn{5}{c}{ Regression Output: } \\
labor $\quad$ Constant & 0.773427 & \\
Std Err of Y Est & 1.099999 & \\
R Squared & 0.057254 & \\
No. of Observations & 24 & \\
Degrees of Freedom & 19 & & \\
& & & & \\
X Coefficient(s) & -0.02287 & 0.010664 & -0.06886 & 0.006341 \\
Std Err of Coef. & 0.022807 & 0.020275 & 0.161124 & 0.129864
\end{tabular}




\section{Table 12: Globalization and Procyclicality--United States}

regression of industry cross-section of procyclicality coefficients against period: 1979 to 1995

initXsh,initMsh,mean(dlXgrowth), mean(dlMgrowth)

labor

Regression Output:

\begin{tabular}{|c|c|c|c|c|}
\hline Constant & & 0.197467 & & \\
\hline Std Err of $Y$ Est & & 0.233701 & & \\
\hline R Squared & & 0.264865 & & \\
\hline No. of Observations & & 24 & & \\
\hline Degrees of Freedom & & 19 & & \\
\hline & Xsht0 & Msht0 & dlXgrow & dlMgrow \\
\hline icient(s) & 0.006593 & -0.00185 & 0.018912 & 0.001808 \\
\hline Std Err of Coef. & 0.011651 & 0.006986 & 0.023663 & 0.021455 \\
\hline
\end{tabular}

K\&L $\quad$ Regression Output:

$\begin{array}{lrrrr}\text { Constant } & 0.881096 & & \\ \text { Std Err of Y Est } & 0.341276 & & \\ \text { R Squared } & 0.469373 & & \\ \text { No. of Observations } & 24 & & \\ \text { Degrees of Freedom } & 19 & & \\ & & & & \\ \text { X Coefficient(s) } & 0.005652 & -0.03226 & 0.135648 & -0.11692 \\ \text { Std Err of Coef. } & 0.017013 & 0.010202 & 0.034555 & 0.031332\end{array}$

KLM Regression Output:

$\begin{array}{lrrrr}\text { Constant } & -0.01344 & & \\ \text { Std Err of Y Est } & 0.352291 & & \\ \text { R Squared } & 0.592679 & & \\ \text { No. of Observations } & 24 & & \\ \text { Degrees of Freedom } & & 19 & & \\ & & & & \\ \text { X Coefficient(s) } & 0.032085 & -0.01305 & -0.00203 & 0.045555 \\ \text { Std Err of Coef. } & 0.017563 & 0.010531 & 0.03567 & 0.032343\end{array}$

